\title{
Effect of site of starch digestion on portal nutrient net fluxes in steers
}

\author{
Pierre Nozière ${ }^{1 *}$, Didier Rémond ${ }^{2}$, Sophie Lemosquet ${ }^{3}$, Béatrice Chauveau $^{1}$, Denys Durand ${ }^{1}$ and Claude Poncet ${ }^{1}$ \\ ${ }^{1}$ Unité de Recherche sur les Herbivores, INRA Theix, 63122 St Genès Champanelle, France \\ ${ }^{2}$ Unité Nutrition et Métabolisme Protéique, INRA Theix, 63122 St Genès Champanelle, France \\ ${ }^{3}$ Unité Mixte de Recherche Production du Lait, INRA, 35590 St Gilles, France
}

(Received 15 September 2004 - Revised 2 March 2005 - Accepted 8 March 2005)

\begin{abstract}
Processing of maize grain is known to modulate the site of starch digestion, thus the nature and amount of nutrients delivered for absorption. We assessed the effect of site of starch digestion on nutrient net fluxes across portal-drained viscera (PDV). Three steers, fitted with permanent digestive cannulas and blood catheters, successively received two diets containing $35 \%$ starch as dent maize grain. Diets differed according to maize presentation: dry and cracked (by-pass, BP) $v$. wet and ground (control, C). Ruminal physicochemical parameters were not significantly affected. Between C and BP, the decrease in ruminal starch digestion was compensated by an increase in starch digestion in the small intestine. The amount of glucose and soluble $\alpha$-glucoside reaching the ileum was not affected. The amount of glucose disappearing in the small intestine increased from 238 to $531 \mathrm{~g} / \mathrm{d}$ between $\mathrm{C}$ and BP, but portal net flux of glucose remained unchanged $(-97 \mathrm{~g} / \mathrm{d})$. The portal $\mathrm{O}_{2}$ consumption and net energy release were not significantly affected, averaging $16 \%$ and $57 \%$ of metabolizable energy intake, respectively. The whole-body glucose appearance rate, measured by jugular infusion of $\left[6,6-{ }^{2} \mathrm{H}_{2}\right] \mathrm{glucose}$, averaged $916 \mathrm{~g} / \mathrm{d}$. The present study shows that the increase in the amount of glucose disappearing in the small intestine of conventionally fed cattle at a moderate intake level induces no change in portal net flux of glucose, reflecting an increase in glucose utilization by PDV. That could contribute to the low response of whole-body glucose appearance rate observed at this moderate level of intestinal glucose supply.
\end{abstract}

Cattle: Digestion: Absorption: Starch: Glucose: Portal-drained viscera

High amounts of cereals incorporated in the diet of high-producing ruminants can induce digestive disorders related to an excessive fermentation rate of starch in the rumen. A shift in site of starch digestion from rumen to intestines could prevent these disorders, but this change influences ruminal fermentation products and microbial protein synthesis, and also the nature of nutrients derived from starch digestion, i.e. volatile fatty acids or glucose, which differ in their energetic efficiency (Owens et al. 1986). The nutritional factors affecting ruminal starch digestion in cattle are well known: nature of cereal, genotype, maturity and grain processing are the main factors controlling the amount of starch escaping ruminal digestion (see reviews by Poncet et al. 1995; Huntington, 1997; Michalet-Doreau \& Doreau, 1999). Up to $35 \%$ of ingested starch has been shown to be digested in the small intestine in steers (Axe et al. 1987; Stock et al. 1987) and cows (Rémond et al. 2004), but the extent of starch digestion in the small intestine can be limited by time or surface exposure of starch to enzymes in this compartment, or by a limited capacity of starch-hydrolysing enzymes, principally pancreatic $\alpha$-amylase (Walker \& Harmon, 1995; Swanson et al. 2002) or brush border $\alpha$-glucosidase (Kreikemeier \& Harmon, 1995). Also, the density of glucose transporters decreases markedly between the proximal and the distal portion of the intestine (Ferraris et al. 1989). Thus, a non-negligible amount of starch (Knowlton et al. 1998; Philippeau et al. 1999b; Rémond et al. 2004), glucose and soluble $\alpha$-glucoside (Kreikemeier et al. 1991; Kreikemeier \& Harmon, 1995) can reach the large intestine for subsequent fermentation in both steers and cows. Assessing the metabolism of absorbed glucose by portal-drained viscera (PDV) requires simultaneous measurements of both small intestinal glucose disappearance and net portal flux, which has been attempted using abomasal infusions (Kreikemeier et al. 1991; Kreikemeier \& Harmon, 1995; Taniguchi et al. 1995; Krehbiel et al. 1996; Harmon et al. 2000) but not in conventionally fed animals. The main objective of this study was to assess digestive and portal net nutrient fluxes in steers receiving two diets differing in the partition of starch digestion between rumen and small intestine. In addition, whole-body glucose appearance rate was monitored. We attempted to achieve the shift in starch digestion between rumen and small intestine by modulating DM content and processing a dent maize genotype, as suggested by previous results from cows (Rémond et al. 2004).

\section{Material and methods \\ Animals, experimental design and diets}

Three steers of Salers breed $(296,325$, and $340 \mathrm{~kg}$ body weight (BW); 11, 13 and 12 months at the beginning of measurements) were used. Animals were castrated and surgically fitted with a 
permanent ruminal cannula (internal diameter $60 \mathrm{~mm}$ ) made of polyamide and polyvinyl chloride (Synthesia, Nogent-surMarne, France). Three weeks later, they were surgically fitted with T-shaped cannulas (internal diameter $17 \mathrm{~mm}$ ) made from plastisol (Synthesia) with a gutter-type base placed at the proximal duodenum and the terminal ileum, as well as catheters in the portal and mesenteric veins and mesenteric artery. The surgery was conducted aseptically under general anaesthesia using isoflurane. Surgical procedures and post-surgical care were conducted under conditions approved by the national legislation on the care and use of laboratory animals (statutory order no. 87-848, 19 October 1987, Journal Officiel, France). Catheter patency was maintained by flushing the catheter with physiological saline and twice-weekly filling with heparinized saline. The animals were housed individually and were allowed 6 weeks to recover from surgery, during which period they were adapted to the experimental diet.

Animals received two diets consisting of $36 \%$ hay (first-cut of natural grassland from the Auvergne region, harvested at early ear emergence), $53 \%$ maize grain (dent genotype) and $11 \%$ soyabean meal, on a DM basis. The organic matter (OM) digestibility and metabolizable energy (ME) content of the diets, estimated on the basis of tabulated feed values (INRA, 1989), were $82 \%$ and $12 \cdot 1 \mathrm{MJ} / \mathrm{kg} \mathrm{DM}$, respectively. The same maize grain was incorporated in the two diets but differed in its presentation: wet and ground (control, C) $v$. dry and cracked (by-pass, BP). DM content $\left(103^{\circ} \mathrm{C}, 24 \mathrm{~h}\right)$ and mean particle size measured by sieving (Waldo et al. 1971) were, respectively, $71.5 \%$ and $1.21 \mathrm{~mm}$ for the C grain and $86.9 \%$ and $3.07 \mathrm{~mm}$ for the BP grain. Wet maize was conserved whole in anaerobic bags and ground before distribution. Due to the necessity of using wet grain quickly after opening the anaerobic bag, animals successively received the BP diet (period 1) then the $\mathrm{C}$ diet (period 2). They also received $100 \mathrm{~g} / \mathrm{d}$ mineral supplement $(\mathrm{Ca}-\mathrm{P}-\mathrm{Mg}-\mathrm{Na}, 20: 10: 5: 5 \%)$ containing vitamins and microelements and $100 \mathrm{~g} / \mathrm{d}$ sodium bicarbonate, and had free access to water and block salt. Diets were offered every $4 \mathrm{~h}$ in six equal meals per day $(3,7,11,15,19$ and $23 \mathrm{~h})$ via an automatic feeder. The intake level was fixed at $5 \mathrm{~kg} \mathrm{DM}$, i.e. 1.58 times maintenance requirements for each animal and diet. Each experimental period consisted of 2 weeks of adaptation to diet and 2 weeks of measurements.

\section{Measurements}

Intake, total tract digestibility and nutrient flow. Daily amounts of feed offered and orts were weighed and recorded for individual steers. The DM content $\left(24 \mathrm{~h}\right.$ at $\left.103^{\circ} \mathrm{C}\right)$ was determined weekly for feeds and daily for orts. Composite samples of fresh feeds and orts were pooled for each steer and period for subsequent analysis. Total tract digestibility was determined on 6 consecutive days by total daily faecal collection during the first week of measurements. Faeces were weighed and mixed before sampling. A representative sample $(500 \mathrm{~g})$ was dried $\left(24 \mathrm{~h}\right.$ at $\left.103^{\circ} \mathrm{C}\right)$ for DM content determination. Another representative sample ( $5 \%$ of daily excretion) was pooled for each steer and period and frozen for subsequent analysis. Duodenal and ileal nutrient flows were determined for the digestibility period using $\mathrm{YbCl}_{3}$ as a marker (Siddons et al. 1985). The $\mathrm{Yb}$ solution $(1 \mathrm{~g} \mathrm{Yb}$ dissolved in 1.2 litres of water) was infused continuously $(50 \mathrm{ml} / \mathrm{h})$ into the rumen, following a priming infusion $(1200 \mathrm{ml})$. Infusions began $5 \mathrm{~d}$ before the beginning of sampling digesta, and continued until the end of the digestibility measurement period. Samples of duodenal $(200 \mathrm{~g})$ and ileal $(200 \mathrm{~g})$ contents were collected four times daily every $3 \mathrm{~h}$ on 2 consecutive days in the middle of the digestibility period, providing representative samples of duodenal and ileal contents representing $1.5 \mathrm{~h}$ intervals over $12 \mathrm{~h}$, i.e. three feeding cycles. Samples were weighed and then frozen for subsequent analysis. The amount of duodenal and ileal contents collected over the digestibility period were taken into account in the calculation of faecal digestibility. Fresh feeds, orts, and duodenal, ileal and faecal samples were analysed for ash $\left(550^{\circ} \mathrm{C}, 6 \mathrm{~h}\right)$ and crude protein (Association of Official Analytical Chemists, 1990). Starch (Faisant et al. 1995) and acid detergent fiber (ADF), using $\alpha$-amylase (Van Soest \& Robertson, 1980) were analysed on fresh feeds and orts, and on lyophilized duodenal, ileal and faecal samples. Yb (Siddons et al. 1985) was analysed on lyophilized duodenal, ileal and faecal samples. Duodenal, ileal and faecal samples withdrawn before infusions were used as blank for $\mathrm{Yb}$ determination. Following an extraction procedure derived from Besle et al. (1981), glucose and soluble $\alpha$-glucoside (maltose, maltotriose, maltotetraose, maltopentaose and maltoheptaose) on lyophilized ileal samples were analysed by HPLC (Bio Rad column, HPX 87P) as described by Kaar et al. (1991).

Ruminal microbial synthesis. Ruminal microbial synthesis was determined on $2 \mathrm{~d}$ per animal per period. Two days before the beginning of the digestibility period, samples (1 litre) of ruminal contents were withdrawn at $08.00,10.40$ and 13.20 hours by aspiration via the ruminal cannula using a tube placed in the ventral sac. After sieving $(4 \mathrm{~mm})$, the ruminal liquor was centrifuged $\left(10 \mathrm{~min}, 4^{\circ} \mathrm{C}, 800 \mathrm{~g}\right)$. Liquid-associated bacteria were isolated from supernatant by centrifugation $\left(20 \mathrm{~min}, 4^{\circ} \mathrm{C}, 27000 \mathrm{~g}\right)$. Nucleic acid bases were determined on lyophilized duodenal samples and ruminal bacteria (Lassalas et al. 1993), and $\mathrm{N}$ was determined on lyophilized ruminal bacteria.

Ruminal physicochemical parameters. Ruminal physicochemical parameters were determined on $1 \mathrm{~d}$ per animal per period. At the end of the digestibility period, samples $(50 \mathrm{ml})$ of ruminal liquor were withdrawn at $08.00,10.40$ and 13.20 hours by aspiration via the ruminal cannula using a tube placed in the ventral sac. The $\mathrm{pH}$ was immediately measured using a combination electrode. After filtration $(100 \mu \mathrm{m})$, samples for ammonia and volatile fatty acid (VFA) determination were preserved by adding $0 \cdot 1$ volume orthophosphoric acid at $5 \%(\mathrm{v} / \mathrm{v})$ or 4 volumes $\mathrm{NaCl}$ at $20 \%(\mathrm{w} / \mathrm{v})$, respectively, and then frozen $\left(-15^{\circ} \mathrm{C}\right)$ before analysis. Ammonia was determined colorimetrically by the phenol-hypochlorite automated method, and VFA was determined by GC using 4-methylvaleric acid as an internal standard, as previously described (Nozière et al. 2000).

Portal net nutrient fluxes. Measurements of portal net fluxes were performed on $1 \mathrm{~d}$ per animal per period. One day before or after duodenal and ileal content were sampled, a physiological sterile saline solution ( $\mathrm{pH} 7.4$ ) containing $p$-aminohippuric acid $(10 \% \mathrm{w} / \mathrm{v})$ was continuously infused into the distal mesenteric vein catheter $(60 \mathrm{ml} / \mathrm{h})$ following a prime injection $(20 \mathrm{ml})$ at 06.45 hours to allow determination of portal blood flow by downstream dilution. Blood samples were withdrawn simultaneously from the artery and portal veins eight times daily at $60 \mathrm{~min}$ intervals, i.e. over two successive feeding cycles. Sampling started at 07.30 hours (i.e. $30 \mathrm{~min}$ after a meal). Samples were slowly drawn into blood syringes containing EDTA-K as anticoagulant for determination of $p$-aminohippuric acid, ammonia and glucose (60 min intervals), other metabolites and packed cell volume (120 min intervals). Samples were drawn into heparinized 
gas-tight syringes for $\mathrm{O}_{2}$ determination (120 min intervals). Immediately after sampling, the heparinized gas-tight syringes were sealed and kept on ice, and blood $\mathrm{O}_{2}$ concentration was measured with an oxygen meter (Strathkelvin Instruments, Glasgow, UK) as described by Tucker (1967). Packed cell volume was determined by centrifuging blood in capillary tubes. Blood ammonia and $p$-aminohippuric acid were determined immediately on whole blood by the phenol-hypochlorite and the $N$ - $\alpha$-naphthyl ethylene diamine dichlorhydrate methods, respectively, using a continuous Autoanalyser (Alliance, Méry-sur-Oise, France), as previously described (Nozière et al. 2000).

After adding 0.1 volume of norleucine $(1.25 \mathrm{~mm})$ as an internal standard, blood was deproteinized with $0 \cdot 1$ volume of sulphosalicylic acid $(40 \%, \mathrm{w} / \mathrm{v})$, then kept at $-15^{\circ} \mathrm{C}$ for subsequent determination of amino acids and urea by ion-exchange chromatography on the physiological column of a Beckman Autoanalyser (model 6300, Beckman Instruments, Palo Alto, CA, USA). Plasma was kept at $-15^{\circ} \mathrm{C}$ for subsequent enzymatic determination of $\beta$-hydroxybutyrate, glucose and lactate, using a multianalyser (Elan, Merck-Clevenot, Nogent-sur-Marne, France) as previously described (Han et al. 2002). Whole blood was kept at $-80^{\circ} \mathrm{C}$ for subsequent determination of VFA by GC with 2-ethylbutyric acid as internal standard, after deproteinization with metaphosphoric acid, as described by Nozière et al. (2000). Blood flow through PDV was calculated as described by Katz \& Bergman (1969). Plasma flow was calculated from blood flow and packed cell volume as described by Nozière et al. (2000). Net fluxes of metabolites and $\mathrm{O}_{2}$ across PDV were calculated as described by Katz \& Bergman (1969). Positive net fluxes represented net release in the vein, whereas negative net fluxes represented net uptake by tissues. Totalling of net release of energy was based on heats of combustion of 876 (acetate), 1528 (propionate), 2310 (four-carbon VFA and $\beta$-hydroxybutyrate), 2838 (five-carbon VFA), 1368 (lactate) and 2001 (amino acids) kJ ME per mol.

Whole-body glucose appearance rate. On the day portal net fluxes were measured, a physiological sterile saline solution $(\mathrm{pH}$ $7 \cdot 4$ ) containing $\left[6,6-{ }^{2} \mathrm{H}_{2}\right]$ glucose $(70 \mathrm{~g} / \mathrm{l})$ was continuously infused $(1.65 \mathrm{~g} / \mathrm{h})$ following a priming infusion $(1.32 \mathrm{~g})$ at 12.50 hours, via a catheter placed the day before into the jugular vein. Arterial blood $(7.5 \mathrm{ml})$ was sampled in tubes containing EDTA-K 90, 105 and $120 \mathrm{~min}$ after the beginning of infusion. Jugular blood withdrawn before injection was used as blank for $\left[6,6-{ }^{2} \mathrm{H}_{2}\right]-$ glucose determination. After deproteinization with 1 volume of $1 \cdot 2 \mathrm{M}-\mathrm{HClO}_{4}$, plasma was kept at $-80^{\circ} \mathrm{C}$ before glucose (Kone Instruments Corporation, Espoo, Finland) and $\left[6,6-{ }^{2} \mathrm{H}_{2}\right]$ glucose enrichment by GC-MS (GC 8060 chromatograph coupled to a VG Platform II, Fisons Instruments, Altrincham, UK) determination, as described by Lemosquet et al. (2004b). The wholebody glucose appearance rate (WBGRa, g/h), accounting for gluconeogenesis plus glycogenolysis plus intestinal absorption of glucose, was determined according to the following equation:

$$
\mathrm{WBGRa}=F \times\left(I E_{\mathrm{inf}} / I E_{\mathrm{p}}-1\right)
$$

where $F$ is $\left[6,6-{ }^{2} \mathrm{H}_{2}\right]$ glucose infusion rate $(\mathrm{g} / \mathrm{h}), I E_{\mathrm{p}}(\mathrm{mol} \%$ excess) is plasma $\left[6,6-{ }^{2} \mathrm{H}_{2}\right]$ glucose enrichment and $I E_{\text {inf }}$ is isotopic enrichment of the infusate (i.e. $98 \mathrm{~mol} \%$ excess).

In situ starch degradability. In situ ruminal degradation was measured for both $\mathrm{C}$ and BP maize grains. Grains (3g DM) were placed in $5 \times 10 \mathrm{~cm}$ nylon bags (pore size $53 \mu \mathrm{m}$, Ankom
Co., Fairport, NY, USA), with presentation similar to that fed to steers for duodenal fluxes measurement. Incubations were performed in duplicate during 3, 6, 9, 15, 24 and $48 \mathrm{~h}$ in the rumen of fistulated cows fed a whole-plant maize silage-based diet. Starch was analysed in feed and in situ residues (Faisant et al. 1995). The theoretical degradability of starch was calculated by the step-bystep method (Kristensen et al. 1982) with a fixed particle passage rate of 0.04 per h. Since fitting to first-order kinetic model using the non-linear regression procedure failed to converge, the fractional degradation rate was determined by logarithmic transformation followed by linear regression (Mertens, 1993).

\section{Statistical analyses}

Due to experimental constraints, treatment and period effects were confounded in this trial. Data were analysed by ANOVA using the MIXED procedure of Statistical Analysis Systems (1996) with treatment as fixed effect and animal as random effect. Significance was declared at $P<0.05$, and $P<0.10$ was considered a trend.

\section{Results}

\section{Digestion}

DM, organic matter and starch digestion. DM and OM intake were similar between treatments, averaging 4815 and $4625 \mathrm{~g} / \mathrm{d}$, respectively (Table 1). The total tract digestibility of OM decreased from 80 to $74 \%$ of intake between C and BP. Although it did not reach statistical significance, this was mainly related to a decrease in $\mathrm{OM}$ digestion in the rumen from 42 to $34 \%$. The amount of starch intake was comparable for both $\mathrm{C}$ and BP, averaging $1757 \mathrm{~g} / \mathrm{d}$. The total tract digestibility of starch tended to decrease from 96 to $91 \%$ of starch intake between C and BP. Although it did not reach statistical significance, this was related to a decrease in starch digestion in the rumen (74 to $55 \%$ ) that was highly compensated by an increase in starch digestion in the small intestine (14 to $30 \%$ ). The amount of starch apparently digested in the small intestine changed from 238 to $531 \mathrm{~g} / \mathrm{d}$ between $\mathrm{C}$ and BP. The amount of glucose and soluble $\alpha$-glucoside reaching the ileum was similar between treatments, averaging 79 and $100 \mathrm{~g} / \mathrm{d}$ for $\mathrm{C}$ and $\mathrm{BP}$ respectively. It corresponded to glucose, maltose, maltotriose, maltotetraose, maltopentaose and maltoheptaose with respective molar percentages of $38,44,16,1 \cdot 8,0 \cdot 3$ and $0 \cdot 3$ (Fig. 1).

$A D F$ and nitrogen digestion. The amounts of ADF intake were similar between treatments, averaging $718 \mathrm{~g} / \mathrm{d}$ (Table 2). The total tract digestibility of ADF changed from 65 to $50 \%$ of intake between $\mathrm{C}$ and BP. Although it did not reach statistical significance, this was mainly related to a decrease in ADF digestion in the intestines from 18 to $8 \%$. The amount of $\mathrm{N}$ intake was similar between treatments, averaging $106 \mathrm{~g} \mathrm{~N} / \mathrm{d}$. Duodenal $\mathrm{NH}_{3}$ and non- $\mathrm{NH}_{3} \mathrm{~N}$ flows were similar between treatments, averaging 2.8 and $114.8 \mathrm{~g} / \mathrm{d}$, respectively. Microbial contribution to duodenal non- $\mathrm{NH}_{3} \mathrm{~N}$ flow, as measured from liquid-associated bacteria composition, did not differ significantly between treatments, averaging 58 and $47 \%$ for $\mathrm{C}$ and $\mathrm{BP}$, respectively. Assuming liquid-associated bacteria underestimated microbial $\mathrm{N}$ flow to the duodenum by $20 \%$ (Yang \& Poncet, 1993), and an endogenous flow of $6 \mathrm{~g} \mathrm{~N} / \mathrm{d}$, the ruminal degradability of dietary $\mathrm{N}$ was estimated to be 73 and $58 \%$ for $\mathrm{C}$ and $\mathrm{BP}$, respectively. Ileal 
Table 1. Intake and digestion of organic matter (OM) and starch in three steers fed diets differing by presentation of maize grain: wet and ground (control) $v$. dry and cracked (by-pass)

(Values are means with their standard errors)

\begin{tabular}{|c|c|c|c|c|}
\hline & \multicolumn{2}{|c|}{ Treatment } & \multirow[b]{2}{*}{ SE } & \multirow[b]{2}{*}{$P$} \\
\hline & Control & By-pass & & \\
\hline DM intake (g/d) & 4806 & 4824 & 27 & 0.69 \\
\hline \multicolumn{5}{|l|}{ OM } \\
\hline intake $(g / d)$ & 4619 & 4631 & 25 & $0 \cdot 77$ \\
\hline \multicolumn{5}{|c|}{ Apparently digested in the rumen } \\
\hline$g / d$ & 1920 & 1582 & 123 & $0 \cdot 17$ \\
\hline$\%$ intake & $41 \cdot 6$ & $34 \cdot 2$ & $2 \cdot 7$ & $0 \cdot 16$ \\
\hline \multicolumn{5}{|c|}{ Apparently digested in the small intestine } \\
\hline$g / d$ & 1076 & 1443 & 326 & 0.48 \\
\hline$\%$ intake & $23 \cdot 3$ & $31 \cdot 1$ & $7 \cdot 0$ & 0.49 \\
\hline \multicolumn{5}{|c|}{ Apparently digested in the large intestine } \\
\hline$g / d$ & 693 & 396 & 191 & 0.39 \\
\hline$\%$ intake & $15 \cdot 0$ & 8.6 & $4 \cdot 1$ & 0.39 \\
\hline \multicolumn{5}{|c|}{ Apparently digested in the total tract } \\
\hline$g / d$ & 3689 & 3421 & 81 & 0.05 \\
\hline$\%$ intake & $79 \cdot 9$ & 73.9 & 1.6 & 0.02 \\
\hline \multicolumn{5}{|l|}{ Starch } \\
\hline Intake (g/d) & 1736 & 1778 & 11 & 0.12 \\
\hline \multicolumn{5}{|c|}{ Apparently digested in the rumen } \\
\hline$g / d$ & 1277 & 969 & 107 & 0.18 \\
\hline$\%$ intake & 73.5 & 54.5 & $6 \cdot 0$ & $0 \cdot 16$ \\
\hline \multicolumn{5}{|c|}{ Apparently digested in the small intestine } \\
\hline$g / d$ & 238 & 531 & 89 & $0 \cdot 15$ \\
\hline$\%$ intake & 13.7 & $29 \cdot 9$ & $5 \cdot 0$ & 0.15 \\
\hline \multicolumn{5}{|c|}{ Apparently digested in the large intestine } \\
\hline$g / d$ & 150 & 114 & 40 & 0.60 \\
\hline$\%$ intake & $8 \cdot 6$ & $6 \cdot 5$ & $2 \cdot 3$ & 0.59 \\
\hline \multicolumn{5}{|c|}{ Apparently digested in the total tract } \\
\hline$g / d$ & 1664 & 1615 & 21 & 0.23 \\
\hline$\%$ intake & $95 \cdot 8$ & $90 \cdot 8$ & $0 \cdot 8$ & 0.05 \\
\hline \multicolumn{5}{|c|}{ Ileal glucose and soluble $\alpha$-glucoside } \\
\hline $\mathrm{g} / \mathrm{d}$ & 79 & 100 & 10 & $0 \cdot 27$ \\
\hline
\end{tabular}

$\mathrm{NH}_{3}$ and non- $\mathrm{NH}_{3} \mathrm{~N}$ flows and faecal $\mathrm{N}$ excretion were similar between treatments, averaging $1.7,44.6$ and $35.4 \mathrm{~g} \mathrm{~N} / \mathrm{d}$, respectively.

Ruminal parameters. Ruminal parameters were not significantly affected by treatments, ranging from 6.28 to 6.54 for $\mathrm{pH}$, from 7.17 to $5.64 \mathrm{~mm}$ for ammonia, and from 104.2 to $97.2 \mathrm{~mm}$ for total VFA between $\mathrm{C}$ and BP, respectively (Table 3). The

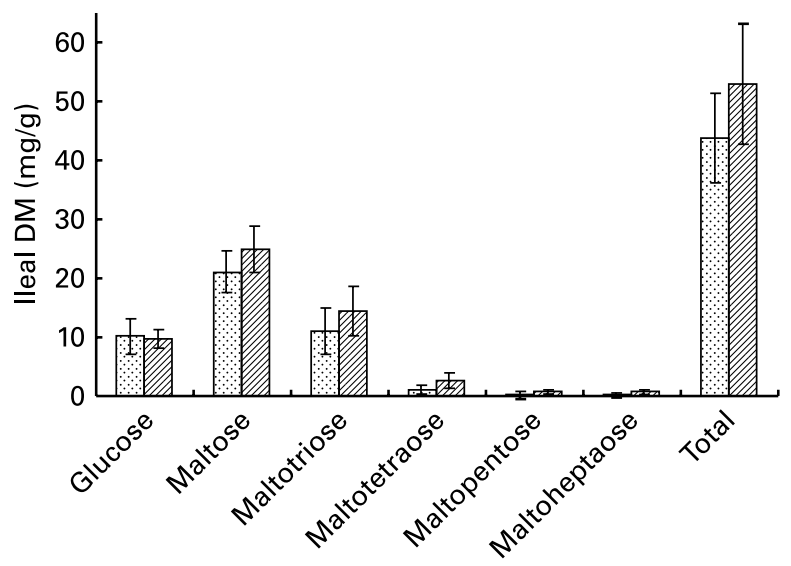

Fig. 1. Concentrations of glucose and soluble $\alpha$-glucoside in ileal content of three steers fed diets differing by presentation of maize grain: wet and ground (control, 图) v. dry and cracked (by-pass, Values are means with their standard errors represented by vertical bars.
Table 2. Intake and digestion of acid detergent fibre (ADF) and nitrogen in three steers fed diets differing by presentation of maize grain: wet and ground (control) $v$. dry and cracked (by-pass)

(Values are means with their standard errors)

\begin{tabular}{|c|c|c|c|c|}
\hline & \multicolumn{2}{|c|}{ Treatment } & \multirow[b]{2}{*}{ SE } & \multirow[b]{2}{*}{$P$} \\
\hline & Control & By-pass & & \\
\hline \multicolumn{5}{|l|}{ ADF } \\
\hline Intake $(g / d)$ & 735 & 701 & 34 & 0.34 \\
\hline \multicolumn{5}{|c|}{ Apparently digested in the rumen } \\
\hline$g / d$ & 340 & 292 & 58 & 0.62 \\
\hline$\%$ intake & $46 \cdot 6$ & $41 \cdot 3$ & $7 \cdot 9$ & 0.68 \\
\hline \multicolumn{5}{|c|}{ Apparently digested in the intestines } \\
\hline$g / d$ & 134 & 56 & 36 & 0.21 \\
\hline$\%$ intake & $18 \cdot 4$ & $8 \cdot 3$ & $5 \cdot 3$ & 0.20 \\
\hline \multicolumn{5}{|c|}{ Apparently digested in the total tract } \\
\hline$g / d$ & 474 & 348 & 33 & 0.11 \\
\hline$\%$ intake & $65 \cdot 0$ & $49 \cdot 6$ & $5 \cdot 3$ & 0.18 \\
\hline \multicolumn{5}{|l|}{ Nitrogen } \\
\hline Intake (g/d) & 106 & 106 & 1 & 0.48 \\
\hline Duodenal $N$ flow (g/d) & 115 & 120 & 20 & 0.87 \\
\hline $\mathrm{NH}_{3}-\mathrm{N}(\mathrm{g} / \mathrm{d})$ & $2 \cdot 3$ & $3 \cdot 2$ & 0.4 & 0.26 \\
\hline Non- $\mathrm{NH}_{3}-\mathrm{N}(\mathrm{g} / \mathrm{d})$ & 113 & 117 & 20 & 0.89 \\
\hline Microbial N (g/d) & $65 \cdot 3$ & 54.9 & 7.9 & 0.45 \\
\hline Non-microbial N (g/d) & $47 \cdot 2$ & $62 \cdot 2$ & $16 \cdot 6$ & 0.55 \\
\hline Ileal $N$ flow $(g / d)$ & $47 \cdot 6$ & $45 \cdot 0$ & $10 \cdot 5$ & 0.88 \\
\hline $\mathrm{NH}_{3}-\mathrm{N}(\mathrm{g} / \mathrm{d})$ & $2 \cdot 1$ & $1 \cdot 3$ & 0.4 & 0.31 \\
\hline Non- $\mathrm{NH}_{3}-\mathrm{N}(\mathrm{g} / \mathrm{d})$ & $45 \cdot 5$ & $43 \cdot 7$ & $10 \cdot 1$ & 0.91 \\
\hline Faecal $N$ excretion $(\mathrm{g} / \mathrm{d})$ & $33 \cdot 3$ & 37.5 & 3.5 & 0.31 \\
\hline
\end{tabular}

$\mathrm{ADF}$, acid detergent fibre

VFA molar percentages were similar between treatments, averaging $63,20,1.4,13,1.9$ and 1.1 for acetate, propionate, isobutyrate, butyrate, isovalerate and valerate, respectively.

In situ starch degradability. In situ starch degradability and fractional degradation rate decreased from 51.0 to $29.6 \%$ $(P<0.001)$ and from 3.7 to $2.2 \% / \mathrm{h}(P<0.08)$ in the $\mathrm{C}$ and the BP maize grain, respectively (Fig. 2).

\section{Net fluxes of nutrients across portal-drained viscera}

Arterial concentrations. Arterial concentrations of individual and total VFA, ammonia, urea, essential and total amino acids in blood, and $\beta$-hydroxybutyrate and glucose in plasma were similar between treatments (Table 4). The arterial concentration decreased for lactate and $\mathrm{O}_{2}$, and tended to decrease for non-essential and glycogenic

Table 3. Ruminal $\mathrm{pH}$, volatile fatty acids (VFA) and ammonia concentrations in three steers fed diets differing by presentation of maize grain: wet and ground (control) v. dry and cracked (by-pass)

(Values are means with their standard errors)

\begin{tabular}{|c|c|c|c|c|}
\hline & \multicolumn{2}{|c|}{ Treatment } & \multirow[b]{2}{*}{ SE } & \multirow[b]{2}{*}{$P$} \\
\hline & Control & By-pass & & \\
\hline $\mathrm{pH}$ & $6 \cdot 28$ & $6 \cdot 54$ & $0 \cdot 16$ & 0.37 \\
\hline Ammonia (mM) & $7 \cdot 17$ & 5.64 & 0.64 & 0.23 \\
\hline Total VFA (mм) & $104 \cdot 2$ & $97 \cdot 2$ & $4 \cdot 3$ & 0.37 \\
\hline Acetate (\%) & $63 \cdot 3$ & $62 \cdot 7$ & 1.6 & 0.82 \\
\hline Propionate (\%) & $19 \cdot 5$ & $19 \cdot 7$ & 1.7 & 0.94 \\
\hline Isobutyrate (\%) & 1.4 & $1 \cdot 3$ & 0.1 & 0.40 \\
\hline Butyrate (\%) & $12 \cdot 3$ & $13 \cdot 1$ & 1.0 & 0.55 \\
\hline Isovalerate (\%) & 1.9 & 1.9 & 0.3 & 0.94 \\
\hline Valerate (\%) & $1 \cdot 1$ & $1 \cdot 1$ & 0.1 & 0.63 \\
\hline
\end{tabular}




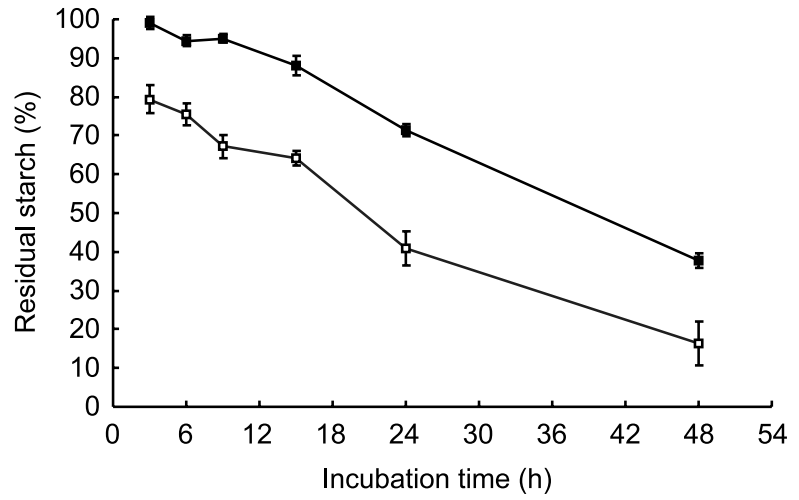

Fig. 2. In situ degradation of maize grain differing by presentation, wet and ground (control, $\square$ ) v. dry and cracked (by-pass, $\mathbf{\square}$ ), in the rumen of three cows fed a whole-plant maize silage-based diet. Values are means with their standard errors represented by vertical bars.

amino acids, from 613 to $419 \mu \mathrm{M}$, from 6574 to $5498 \mu \mathrm{M}$, from 1351 to $1200 \mu \mathrm{M}$ and from 952 to $795 \mu \mathrm{M}$, respectively, between $\mathrm{C}$ and BP. The decrease in both non-essential and glycogenic amino acids appeared mainly related to glutamine (from 269 to $152 \mu \mathrm{M})$ although it did not reach statistical significance.

Portal net fluxes. Portal blood and plasma flows tended to decrease between C and BP (Table 5). Portal net appearance of individual and total VFA, $\beta$-hydroxybutyrate, lactate, essential, non-essential, glycogenic and total amino acids, portal net release of energy, and portal net uptake of glucose, urea and $\mathrm{O}_{2}$ were similar between treatments. Portal net appearance of ammonia tended to decrease from 108 to $73 \mathrm{mmol} / \mathrm{h}$ between $\mathrm{C}$ and $\mathrm{BP}$.

\section{Whole-body glucose appearance rate}

The low variation coefficient of plasma glucose concentration $(1 \cdot 1-6 \cdot 3 \%)$ and ${ }^{2} \mathrm{H}$ enrichment $(0 \cdot 1-2 \cdot 1 \%)$ indicated that the plateau for ${ }^{2} \mathrm{H}$ enrichment in plasma was achieved 90 min after

Table 4. Arterial concentrations $(\mu \mathrm{M})$ of nutrients in three steers fed diets differing by presentation of maize grain: wet and ground (control) v. dry and cracked (by-pass)

(Values are means with their standard errors)

\begin{tabular}{lcccc}
\hline & \multicolumn{2}{c}{ Treatment } & & \\
\cline { 2 - 3 } & Control & By-pass & SE & $P$ \\
\hline Plasma & & & & \\
B-Hydroxybutyrate & 477 & 531 & 75 & 0.66 \\
Lactate & 613 & 419 & 30 & 0.01 \\
Glucose & 4239 & 4376 & 225 & 0.61 \\
Blood & & & & \\
Acetate & 838 & 950 & 202 & 0.73 \\
Propionate & $28 \cdot 3$ & 25.6 & 9.0 & 0.85 \\
Isobutyrate & $2 \cdot 10$ & 1.63 & 0.62 & 0.65 \\
Butyrate & $10 \cdot 2$ & 13.6 & 4.13 & 0.61 \\
Isovalerate & 1.70 & 2.30 & 0.77 & 0.64 \\
Valerate & 0.033 & 0.100 & 0.047 & 0.42 \\
Ammonia & 58.0 & 65.0 & 36.0 & 0.61 \\
Urea & 1588 & 1813 & 248 & 0.59 \\
Essential amino acids & 647 & 709 & 55 & 0.40 \\
Non-essential amino acids & 1351 & 1200 & 79 & 0.07 \\
Glycogenic amino acids & 952 & 795 & 38 & 0.05 \\
Total amino acids & 1998 & 1908 & 97 & 0.25 \\
O & 6574 & 5498 & 452 & 0.03 \\
\hline
\end{tabular}

Table 5. Portal net fluxes of nutrients in three steers fed diets differing by presentation of maize grain: wet and ground (control) $v$. dry and cracked (by-pass)

(Values are means with their standard errors)

\begin{tabular}{|c|c|c|c|c|}
\hline & \multicolumn{2}{|c|}{ Treatment } & \multirow[b]{2}{*}{ SE } & \multirow[b]{2}{*}{$P$} \\
\hline & Control & By-pass & & \\
\hline Portal blood flow (l/h) & 659 & 550 & 52 & 0.10 \\
\hline Portal plasma flow $(1 / h)$ & 466 & 407 & 35 & 0.11 \\
\hline \multicolumn{5}{|l|}{ Portal net fluxes $(\mathrm{mmol} / \mathrm{h})$} \\
\hline Acetate & 695 & 602 & 59 & 0.38 \\
\hline Propionate & 187 & 176 & 12 & 0.22 \\
\hline Isobutyrate & $8 \cdot 14$ & $7 \cdot 38$ & $1 \cdot 24$ & 0.66 \\
\hline Butyrate & $37 \cdot 5$ & 38.8 & $9 \cdot 3$ & 0.92 \\
\hline Isovalerate & $9 \cdot 41$ & 9.35 & 1.94 & 0.98 \\
\hline Valerate & $2 \cdot 76$ & $2 \cdot 88$ & 0.66 & 0.87 \\
\hline Total volatile fatty acids & 940 & 836 & 72 & 0.41 \\
\hline$\beta$-Hydroxybutyrate & 71.5 & $81 \cdot 3$ & $16 \cdot 6$ & 0.72 \\
\hline Lactate & $36 \cdot 1$ & $26 \cdot 4$ & $27 \cdot 6$ & 0.74 \\
\hline Glucose & $-22 \cdot 4$ & $-22 \cdot 7$ & $29 \cdot 5$ & 0.98 \\
\hline Ammonia & $108 \cdot 0$ & $73 \cdot 0$ & $9 \cdot 1$ & 0.10 \\
\hline Urea & $-80 \cdot 1$ & $-64 \cdot 2$ & $36 \cdot 0$ & 0.17 \\
\hline Essential amino acids & $34 \cdot 8$ & $26 \cdot 0$ & $14 \cdot 0$ & 0.69 \\
\hline Non-essential amino acids & $9 \cdot 7$ & $16 \cdot 2$ & $20 \cdot 5$ & 0.81 \\
\hline Glycogenic amino acids & $3 \cdot 1$ & $13 \cdot 0$ & 14.5 & 0.62 \\
\hline Total amino acids & $44 \cdot 4$ & $42 \cdot 2$ & $33 \cdot 0$ & 0.96 \\
\hline $\mathrm{O}_{2}$ & -892 & -712 & 89 & 0.20 \\
\hline Portal net release energy $(\mathrm{kJ} / \mathrm{h})$ & 1363 & 1252 & 114 & 0.48 \\
\hline
\end{tabular}

the beginning of infusion (Lemosquet et al. 2004a,b). The WBGRa was measured on the three steers with the BP treatment, and averaged 932 (SE 21) g/d. Since blood ran out slowly from the catheters during the second period for two animals, the WBGRa was measured on only one steer receiving the control treatment, and was $869 \mathrm{~g} / \mathrm{d}$. This value was lower than the $951 \mathrm{~g} / \mathrm{d}$ measured on the same steer with the BP treatment.

\section{Discussion}

Due to the necessity of using wet grain quickly after opening the anaerobic bag, dietary treatments and period effects were statistically confounded. Many factors concur to attribute differences between $\mathrm{C}$ and $\mathrm{BP}$ to dietary treatments: the short duration of the experiment (4 weeks between the first and the second period), the stability in body weight and intake between the two periods and the expected differences observed between $\mathrm{C}$ and BP. However, this limitation in the experimental design has been considered in the discussion of results.

\section{Digestibility and ruminal digestion of organic matter, starch and cell walls}

Compared with other studies on steers fed maize providing starch at 35-50\% of DM intake (Cole et al. 1976; Lee et al. 1982; Kung et al. 1992; Philippeau et al. 1999b), the total tract digestibility of $\mathrm{OM}$, starch and ADF was high in our trial: 74-80v. 64-6\% for OM; $91-96$ v. 76-99\% for starch; 50-65\% v. 44\% for ADF. No major effect of feeding frequency on total-tract OM digestion has been reported in steers at restricted intake (review by Galyean \& Owens, 1991). This high digestibility could be due to the nature of the feedstuffs, but also to the low intake level in the present study (14 g OM/kg BW) compared to others (13-25 g OM/kg BW). In cattle fed between 20 and $60 \%$ concentrate, Doreau 
et al. (2000) reviewed that an increase in intake of $10 \mathrm{~g} / \mathrm{kg} \mathrm{BW}$ induces an average decrease in digestibility of $2.0 \mathrm{~g} / 100 \mathrm{~g}$ for $\mathrm{OM}$ and $5 \cdot 2 \mathrm{~g} / 100 \mathrm{~g}$ for ADF. The moderate intake level in the present study, corresponding to $90 \%$ ad libitum, illustrates the difficulty of reaching a high intake when animals are fitted with both catheters and intestinal cannulas.

The contribution of the rumen to digestion of OM (52-46\%) and starch $(77-60 \%)$ was consistent with the values previously reported in steers fed maize providing $35-50 \%$ of DM intake: 40-77\% for OM (Kung et al. 1992; Philippeau et al. 1999b) and $43-96 \%$ for starch (Boss \& Bowman, 1996; Philippeau et al. 1999b). The decrease in OM ruminal digestion between $\mathrm{C}$ and $\mathrm{BP}$ was related to a decrease in starch digestion $(-19 \mathrm{~g} / 100 \mathrm{~g})$, whereas cell wall digestion was affected little $(-5 \mathrm{~g} / 100 \mathrm{~g})$. This reflects that no large modifications in cellulolytic microbial activity occurred, which is consistent with the physicochemical ruminal parameters that remained comparable between treatments. Also, the portal net appearance of VFA was not significantly affected. The decrease in ruminal digestion of starch between $\mathrm{C}$ and BP may be attributed to a decreased accessibility of starch granules. This is consistent with the decreased degradability of dietary $\mathrm{N}$ between $\mathrm{C}$ and $\mathrm{BP}$, since ruminal starch degradation is closely related to protein degradation in the grain endosperm (McAllister et al. 1993). It may be emphasized that dietary $\mathrm{N}$ ruminal degradability with diet BP $(58 \%)$ was consistent with the value of $56 \%$ given by the French nitrogen feeding system (INRA, 1989).

As intended, ruminal starch digestion was lower with the wet and ground grain (BP) than with the dry and cracked grain (C). Increasing DM content (Knowlton et al. 1998) and/or mean particle size (Galyean et al. 1979; Rémond et al. 2004) has already been shown to decrease ruminal starch digestion of maize grain. The $55 \%$ ruminal starch digestibility with the BP treatment is consistent with previous results obtained with dry rolled grain of dent maize genotype with a comparable particle size for both steers (61\%; Philippeau et al. 1999b) and cows (54\%; Rémond et al. 2004). With the $\mathrm{C}$ grain, $20 \%$ starch disappeared in the first $3 \mathrm{~h}$. With grains exhibiting a rapidly degradable fraction of starch of less than $20 \%$, starch washed out of the bag at time zero accounted for less than $8 \%$ of incubated starch (Philippeau et al. 1999a). Particulate losses may thus only partly explain the decrease in starch in situ degradability between $\mathrm{C}$ and BP grain, that was also related to a decrease in fractional degradation rate, consistently with previous results (Lykos \& Varga, 1995; Rémond et al. 2004). The extent of the decrease in starch in situ degradability between $\mathrm{C}$ and $\mathrm{BP}$ grain reached $21 \mathrm{~g} / 100 \mathrm{~g}$, which was close to the nineteen-point decrease in in vivo ruminal starch digestion. In situ and in vivo variation of ruminal starch digestion induced by the particle size of maize grain has been reported previously to be quantitatively similar (Rémond et al. 2004). In situ starch degradability was lower than in vivo ruminal starch digestion. This is in line with the fact that in situ underestimates ruminal digestion for slowly degradable starch (Nocek \& Tamminga, 1991; Offner \& Sauvant, 2004). This may be related to a lower accessibility of starch to microbes, thus a lower expression of amylase activity in the bags (Nozière \& Michalet-Doreau, 1997), where grains are not submitted to mastication. Nevertheless, the extent of the difference between in situ and in vivo measurements $(24 \mathrm{~g} / 100 \mathrm{~g}$ in the present study) is surprisingly high, but remains consistent with results previously obtained with a dent variety (Nozière et al. 2003).
The amount of starch escaping ruminal digestion ranged from 460 to $804 \mathrm{~g} / \mathrm{d}$ between $\mathrm{C}$ and $\mathrm{BP}$, and intestinal digestion of BP starch took place almost exclusively in the small intestine. Limits to starch digestion in the small intestine may be related to time and surface exposure of starch to enzymes in this compartment, or to a limited capacity of starch-hydrolysing enzymes (Owens et al. 1986). In the present study, the limited level of intake favoured a high exposure time in the intestines. It may also have been expected that starch reaching the duodenum was mainly distributed in the small particles, as observed by Philippeau et al. (1999b), favouring a high surface exposure of starch to enzymes in the intestines. No plateau in the amount of starch digested in the small intestine was observed when the amount of starch entering the duodenum increased to $1500 \mathrm{~g} / \mathrm{d}$ in steers (Kreikemeier et al. 1991). This suggests that the capacity of starch-hydrolysing enzymes was not a limiting factor in our study, although the increase in the amount of starch reaching the duodenum between $\mathrm{C}$ and BP may have decreased pancreatic $\alpha$-amylase secretion (Swanson et al. 2002).

The amount of total glucose and soluble $\alpha$-glucoside accounted for $36 \%(w / w)$ of starch apparently reaching the ileum (222 and $277 \mathrm{~g} / \mathrm{d}$ with C and BP, respectively), which is consistent with the value of $28 \%$ reported by Kreikemeier \& Harmon (1995) in steers receiving abomasal infusions of maize starch. Also, the contribution of glucose to total soluble $\alpha$-glucoside reaching the ileum was $18-23 \%(w / w)$ in our study, which is also consistent with the value of $18 \%$ reported by Kreikemeier \& Harmon (1995). This indicates that glucose production exceeded glucose disappearance capacity, which may be related to the decreasing transport activity between the proximal and the distal regions of the intestine (Ferraris et al. 1989), and to a low contribution of passive diffusion in the glucose absorption process (Krehbiel et al. 1996). In our study, the limitation in glucose disappearance had no major quantitative impact, since the luminal concentration of glucose at the ileum remained low $(<6 \mathrm{~mm})$. This is in good agreement with the simulation of glucose concentration at the distal small intestine proposed by Huntington (1997), with a limitation of transport by sodium-glucose transporters and a supply of duodenal glucose close to that measured in the present study $(500-1000 \mathrm{~g} / \mathrm{d})$.

\section{Portal net flux and whole-body appearance rate of glucose}

Portal blood flow averaged 187 litres/d per $\mathrm{kg} \mathrm{BW}^{075}$ for BP and $\mathrm{C}$, which is consistent with the estimation derived from ME intake (194 litres/d per kg BW ${ }^{075}$ ) in cattle (Huntington, 1984). Also, the small decrease in portal blood flow between $\mathrm{C}$ and BP may be attributed to the low decrease in OM digestibility.

Since starch determination in digestive contents accounted for both glucose and soluble and insoluble $\alpha$-glucoside, the amount of glucose that disappeared in the small intestine corresponded to the amount of starch apparently digested in this compartment. Although it increased from 238 to $531 \mathrm{~g} / \mathrm{d}$ between C and BP, the portal net flux of glucose remained unchanged and negative $(-97 \mathrm{~g} / \mathrm{d})$. Net uptake of arterial glucose by PDV has been clearly demonstrated in forage-fed ruminants (Huntington, 1984). Portal net appearance has been observed when large amounts of starch $\left(8.4-13.3 \mathrm{~g} / \mathrm{d}\right.$ per $\left.\mathrm{kg} \mathrm{BW}^{075}\right)$ were infused into the duodenum in cows (Huntington \& Reynolds, 1986) and steers (Taniguchi et al. 1995; Harmon et al. 2000), and when large amounts of infused starch $\left(5-11.3 \mathrm{~g} / \mathrm{d}\right.$ per $\left.\mathrm{kg} \mathrm{BW}^{075}\right)$ were apparently digested in the small intestine in steers (Kreikemeier et al. 
1991; Kreikemeier \& Harmon, 1995). In contrast, with a lower amount of starch infused to the duodenum $(4.9 \mathrm{~g} / \mathrm{d}$ per $\mathrm{kg}$ $\mathrm{BW}^{075}$ ), portal net flux of glucose remained negative (net uptake) and unchanged in cows (Huntington \& Reynolds, 1986), as observed in the present study where the amount of starch apparently digested in the small intestine was moderate $\left(2.9-6.8 \mathrm{~g} / \mathrm{d}\right.$ per $\left.\mathrm{kg} \mathrm{BW}^{075}\right)$. Also, in sheep, a duodenal infusion of glucose reaching $7.4 \mathrm{~g} / \mathrm{d}$ per $\mathrm{kg} \mathrm{BW}^{075}$ was not sufficient to shift portal net flux of glucose from net uptake to net appearance (Piccioli Cappelli et al. 1997), and in steers an increase in maize starch intake from 15.3 to $30.5 \mathrm{~g}$ starch $/ \mathrm{d}$ per $\mathrm{kg} \mathrm{BW}^{0.75}$ decreased portal net uptake of glucose from -138 to $-52 \mathrm{~g} / \mathrm{d}$, without shifting to net appearance (Huntington et al. 1996). The portal net uptake of glucose measured in the present study $(-97 \mathrm{~g} / \mathrm{d}$ with a maize starch intake of $22.7 \mathrm{~g} / \mathrm{d}$ per $\mathrm{kg} \mathrm{BW}^{0.75}$ ) is in good agreement with these results.

Our results suggest that PDV glucose use was increased between $\mathrm{C}$ and BP. Previous studies reported that utilization of glucose in portal tissues increased significantly (Balcells et al. 1995) or not (Piccioli Cappelli et al. 1997) as a result of duodenal glucose infusion in sheep. Also, Harmon et al. (2000) reported that shifting the site of starch infusion from rumen to small intestine increased glucose utilization by PDV tissues in steers. Janes et al. (1985) found in sheep that use of arterial glucose by mesenteric-drained viscera (MDV) was similar for forage and concentrate diets, and that nearly $100 \%$ of small intestinal starch disappearance was accounted for as net glucose appearance across MDV with the concentrate diet. Reynolds \& Huntington (1988) and Huntington et al. (1996) reported a net glucose appearance across MDV in concentrate-fed steers whereas net glucose flux across PDV was negative. These results suggest that the increase in PDV glucose use between C and BP may be attributed to non-MDV tissues. In forage-fed animals, the contribution of non-MDV tissues to PDV use of arterial glucose has been shown to reach 19-42\% (Reynolds \& Huntington, 1988), or more than $50 \%$ (Seal et al. 1992; Seal \& Parker, 1994) in steers, and $58-72 \%$ (Han et al. 2002) in sheep. When MDV measurements were performed in the cranial mesenteric vein (draining $85 \%$ of the whole small intestine), the contribution of nonMDV reached $84 \%$ in sheep (Rémond et al. 2003).

In our trial, portal net flux of glucose remained unchanged, suggesting that WBGRa probably increased little, and only increased when endogeneous glucose production increased and/ or glycogenolysis decreased. Similarly, when duodenal glucose infusion in lactating dairy cows was increased from 2.9 to $6.8 \mathrm{~g} / \mathrm{d}$ per $\mathrm{kg} \mathrm{BW}^{075}$, WBGRa did not change (Lemosquet et al. 2004a). Unfortunately, we did not measure WBGRa in both treatments, except on one steer, for which the increase in the amount of starch digested in the small intestine of $258 \mathrm{~g} / \mathrm{d}$ (from 210 to $468 \mathrm{~g} / \mathrm{d}$ ) was accompanied by a limited increase in WBGRa of $82 \mathrm{~g} / \mathrm{d}$ (from 869 to $951 \mathrm{~g} / \mathrm{d}$ ). However, the mean WBGRa value (11.8 (SE 0.5) $\mathrm{g} / \mathrm{d}$ per $\mathrm{kg} \mathrm{BW}^{0.75}$ ) obtained with our four data (three BP plus one $\mathrm{C}$ ) is in the range of total glucose splanchnic production measured on steers fed concentrate diets, i.e. $7-16 \mathrm{~g} / \mathrm{d}$ per $\mathrm{kg} \mathrm{BW}^{075}$ (Reynolds et al. 1991; Eisemann et al. 1996; Huntington et al. 1996).

\section{Nitrogen balance}

Compared to total $\mathrm{N}$ apparently digested in the digestive tract (72.3 and $68.9 \mathrm{~g} \mathrm{~N} / \mathrm{d}$ for $\mathrm{C}$ and $\mathrm{BP}$, respectively), portal net fluxes of amino acids (17.7 and $19.7 \mathrm{~g} \mathrm{~N} / \mathrm{d})$ were consistent with the values $(20.4-25.2 \mathrm{~g} \alpha$-amino $\mathrm{N} / \mathrm{d})$ reported in steers with $87-115 \mathrm{~g} \mathrm{~N}$ apparently digested in the digestive tract (Taniguchi et al. 1995). Portal net appearance of ammonia was lower in our experiment ( 36.3 and $24.5 \mathrm{~g} \mathrm{~N} / \mathrm{d})$ than in the Taniguchi et al. (1995) experiment $(66.7-98.9 \mathrm{~g} \mathrm{~N} / \mathrm{d})$, due to a lower ruminal $\mathrm{NH}_{3}$ concentration $(5 \cdot 6-7 \cdot 2 \mathrm{mM}$ v. $12 \cdot 8-21 \mathrm{~mm})$. The decrease in portal net appearance of ammonia $\mathrm{N}$ between $\mathrm{C}$ and $\mathrm{BP}$ was consistent with the decreased ruminal degradability of dietary N. Portal net uptake of urea $\mathrm{N}$ averaged $-48 \mathrm{~g} \mathrm{~N} / \mathrm{d}$, which remains high compared to predictive models from dietary concentrate (Huntington et al. 1996) or body weight (Eisemann et al. 1996), both predicting $-28 \mathrm{~g} \mathrm{~N} / \mathrm{d}$. This discrepancy was due to values for one animal, as portal net uptake of urea $\mathrm{N}$ averaged $-25 \mathrm{~g} \mathrm{~N} / \mathrm{d}$ for the other two animals. Assuming a portal net flux of urea $\mathrm{N}$ of $-25 \mathrm{~g} \mathrm{~N} / \mathrm{d}$, the totalling of portal amino acid $\mathrm{N}$, ammonia $\mathrm{N}$ and urea $\mathrm{N}$ net fluxes indicates that $46 \mathrm{~g}$ of $\mathrm{N}$ apparently digested was not taken into account in this balance between digestive and portal net fluxes of N. Similarly, Taniguchi et al. (1995) observed that up to $34 \mathrm{~g} \mathrm{~N} / \mathrm{d}$ apparently digested was not recovered in the totalling of $\alpha$-amino $\mathrm{N}$, ammonia $\mathrm{N}$ or urea $\mathrm{N}$ net fluxes across PDV in steers. A portion of ammonia reaching peripheral blood through peritoneal fluid without traversing the liver (Chalmers et al. 1971) may partly account for the discrepancy in the balance between digestive and portal net fluxes of $\mathrm{N}$. The contribution of amino acid peptides to portal net release of total amino acid has been shown to reach $67 \%$ in young forage-fed steers (130 kg BW; Seal \& Parker, 1996). With a similar methodology, this contribution was lower (32\%) in older steers $(260 \mathrm{~kg} \mathrm{BW})$ fed $50 \%$ concentrate diets and was not affected by dietary protein degradability (Han et al. 2001). Assuming a contribution of $35 \%$ in the present experiment, the portal net release of $\mathrm{N}$ from peptides could not exceed $10 \mathrm{~g}$ $\mathrm{N} / \mathrm{d}$. The contribution of salivary, biliary and pancreatic $\mathrm{N}$ secreted in the gut, together with portal net release of $\mathrm{N}$ from proteins and nucleic bases, is probably not sufficient to explain the discrepancy between apparent digestibility and portal net appearance of $\mathrm{N}$, which could reflect $\mathrm{N}$ deposition and/or oxidation in the PDV.

\section{Energy balance}

Oxygen consumption by PDV and the totalling of energy released in the portal vein accounted for 16 and $57 \%$ of ME intake, respectively. These results are consistent with other results from steers fed at a comparable energy intake to the present study: $13-23 \%$ of $\mathrm{ME}$ intake for PDV $\mathrm{O}_{2}$ consumption (Huntington et al. 1988; Reynolds et al. 1991) and 46-71\% of ME intake for portal net energy release (Reynolds \& Huntington, 1988; Reynolds et al. 1992). Totalling of PDV $\mathrm{O}_{2}$ net uptake and energy release as VFA, $\beta$-hydroxybutyrate, lactate and amino acid reached $40.3 \mathrm{MJ} / \mathrm{d}$, i.e. $74 \%$ of ME intake. There are few reports of simultaneous measurements of PDV $\mathrm{O}_{2}$ uptake and energy release. In line with our results, total recovery has been reported to vary from 65 to $93 \%$ of ME intake in cattle (Reynolds \& Huntington, 1988; Eisemann et al. 1996). Sources of energy not taken into account in these recoveries include heat of fermentation, lipids, $\alpha$-keto acids, nucleic acids and peptides. Total VFA, $\beta$-hydroxybutyrate, lactate and amino acid released in the portal vein accounted for 43, 8, 2 and $4 \%$ of ME intake, respectively. This was in line with previous studies on steers (Huntington 
et al. 1988; Reynolds \& Huntington, 1988; Eisemann et al. 1996) for VFA (35-52\%), $\beta$-hydroxybutyrate $(7-9 \%)$ and lactate $(2-$ $5 \%$ ), but our results were lower for amino acids $(5-10 \%)$. This may be related to $\mathrm{N}$ deposition in the PDV, as discussed earlier.

Since ruminal concentrations do not reflect ruminal production or absorption rates, the comparison between ruminal concentrations and portal net appearance is tenuous, but Huntington (1999) suggested the possibility of using ruminal concentrations to indicate VFA proportions available for liver metabolism. In the present study, the molar contribution of acetate, propionate and butyrate to total VFA averaged 73, 20 and 4\%, respectively, for portal net appearance, whereas it averaged 63, 20 and $13 \%$, respectively, for ruminal concentrations. The ratio between portal net appearance and ruminal concentrations was thus the highest for acetate and the lowest for butyrate, which is consistent with many studies (see review by Huntington, 1999) and in line with a decrease in portal recovery with increasing VFA chain length (see review by Rémond et al. 1995). Assuming a portal recovery of $72 \%$ for arterial acetate, and 71,69 and $25 \%$ for acetate, propionate and butyrate produced in the lumen (Nozière $\&$ Hoch, 2005), the production of VFA (acetate + propionate + butyrate) with $\mathrm{C}$ and $\mathrm{BP}$ may account for $76 \%$ of $\mathrm{ME}$ intake, i.e $10.5 \mathrm{~mol} / \mathrm{kg} \mathrm{OM}$ digested, which is consistent with other estimations in steers fed hay/concentrate diets (Sharp et al. 1982; Siciliano-Jones \& Murphy, 1989). Assuming a portal recovery of $87 \%$ of arterial $\beta$-hydroxybutyrate (Kristensen et al. 2000), the production of $\beta$-hydroxybutyrate by PDV tissues may account for $95 \%$ of butyrate not recovered in the portal vein. Although $\beta$-hydroxybutyrate released in the portal vein can also derive from acetate, this suggests that butyrate was not extensively oxidized to $\mathrm{CO}_{2}$ by PDV, as has been suggested by Kristensen et al. (2000) in sheep. This also suggests that limitation of ketogenesis was not achieved in this trial. This is in good agreement with the observations of Krehbiel et al. (1992) in steers receiving a ruminal $150 \mathrm{mmol} / \mathrm{h}$ infusion of butyrate, comparable to the production estimated in the present study.

\section{Conclusion}

To our knowledge, this work constitutes the first attempt to compare both digestive and portal fluxes of nutrients in conventionally fed cattle. The main objective was to assess the role of BP starch on portal absorption of nutrients. With a moderate intake level, no significant changes in the amount and nature of energy reaching the liver via the portal vein were observed. The increase in the amount of glucose disappearing in the small intestine induced no change in portal net flux of glucose, reflecting an increased glucose utilization by PDV. This could contribute to the low response of whole-body glucose appearance rate at this moderate level of intestinal glucose supply observed in the literature data.

\section{Acknowledgements}

The authors thank M. Champion and Limagrain Genetics for their financial support, R. Coudure (AGPM) for providing maize grains, P. Gaydier for assistance in anaesthesia, P. Faure, D. Chassaigne and the staff of 'Les Intrabois' for animal care and help with sampling, C. Flors for in situ measurements, and lastly P. Amblard, E. Aurousseau, S. Gachon, M. Tourret, J. N. Thibeault and M. Vérité for analysis.

\section{References}

Association of Official Analytical Chemists (1990) Official Methods of Analysis, vol. 1, 14th ed., p. 684, Washington, DC: AOAC.

Axe DE, Bolsen KH, Harmon DL, Lee RW, Milliken GA \& Avery TB (1987) Effect of wheat and high-moisture sorghum grain fed singly or in combination on ruminal fermentation, solid and liquid flow, site and extent of digestion and feeding performance of cattle. J Anim Sci 64, 897-906.

Balcells J, Seal CJ \& Parker DS (1995) Effect of intravenous glucose infusion on metabolism of the portal-drained viscera in sheep fed a cereal/ straw-based diet. J Anim Sci 73, 2146-2155.

Besle JM, Lassalas B \& Thivend P (1981) Digestion des glucides cytoplasmiques de la fèveverole par le veau préruminant. Reprod Nutr Dev 21, 629-649.

Boss DL \& Bowman JPG (1996) Barley varieties for finishing steers: II. Ruminal characteristics and rate, site, and extent of digestion. J Anim Sci 74, 1973-1981.

Chalmers MI, Jaffray AE \& White F (1971) Movements of ammonia following intraruminal administration of urea or casein. Proc Nutr Soc 30, $7-17$.

Cole NA, Johnson RR \& Owens FN (1976) Influence of roughage level and corn processing method on site and extent of digestion by beef steers. J Anim Sci 43, 490-496.

Doreau M, Grimaud P \& Michalet-Doreau B (2000) La sous-alimentation chez les ruminants: ses effets sur la digestion. INRA Prod Anim 13, 247-255.

Eisemann JH, Huntington GB \& Catherman DR (1996) Patterns of nutrient interchange and oxygen use among portal-drained viscera, liver, and hindquarters of beef steers from 235 to $525 \mathrm{~kg}$ body weight. J Anim Sci 74, 1812-1831.

Faisant N, Planchot V, Kozlowski F, Pacouret MP, Colonna P \& Champ M (1995) Resistant starch determination adapted to products containing high levels of resistant starch. Sci Aliments 15, 83-89.

Ferraris RP, Lee PP \& Diamond JM (1989) Origin of regional and species differences in intestinal glucose uptake. Am $J$ Physiol 257, G689-G697.

Galyean ML \& Owens FN (1991) Effects of diet composition and level of feed intake on site and extent of digestion in ruminants. In Physiological Aspects of Digestion and Metabolism in Ruminants: Proceedings of the Seventh International Symposium on Ruminant Physiology, Sendai, Japan, pp. 483-514 [T Tsuda, Y Sasaki and R Kawashima, editors]. San Diego, CA: Academic Press.

Galyean ML, Wagner DG \& Owens FN (1979) Corn particle size and site and extent of digestion by steers. J Anim Sci 49, 204-210.

Han XT, Nozière P, Rémond D, Chabrot J \& Doreau M (2002) Effects of nutrient supply and dietary bulk on $\mathrm{O}_{2}$ uptake and nutrient net fluxes across rumen, mesenteric- and portal-drained viscera in ewes. J Anim Sci 80, 1362-1375.

Han XT, Xue B, Hu LH \& Du JZ (2001) Effect of dietary protein degradability on net fluxes of free and peptide amino acids across the portal-drained viscera of steers. J Agric Sci (Camb) 137, 471-481.

Harmon DL, Richards CJ, Swanson KC, Howell JA, Matthews JC, True AD, Huntington GB, Gahr SA \& Russell RW (2000) Influence of ruminal or post ruminal starch on visceral metabolism in steers. In Proceedings of the 15th Symposium on Energy Metabolism in Animals. EAAP Publication no. 103, pp. 273-276 [A Chwalibog and K Jakobsen, editors]. Snekkersten, Denmark: EAAP.

Huntington GB (1984) Relationship of portal blood flow to metabolizable energy intake of cattle. Can J Anim Sci 64, Suppl., 16-17.

Huntington GB (1997) Starch utilization by ruminants: from basics to the bunk. J Anim Sci 75, 852-867. 
Huntington GB (1999) Nutrient metabolism by gastrointestinal tissues of herbivores. In Nutritional Ecology of Herbivores, pp. 312-336 [HJG Jung and GC Fahey, editors]. Savoy, IL: ASAS.

Huntington GB \& Reynolds PJ (1986) Net absorption of glucose, 1-lactate, volatile fatty acids, and nitrogenous compounds by bovine given abomasal infusions of starch or glucose. J Dairy Sci 69, $2428-2436$.

Huntington GB, Varga GA, Glenn BP \& Waldo DR (1988) Net absorption and oxygen consumption by Holstein steers fed alfalfa or orchardgrass silage at two equalized intakes. J Anim Sci 66, 1292-1302.

Huntington GB, Zetina EJ, Whitt JM \& Potts W (1996) Effects of dietary concentrate level on nutrient absorption, liver metabolism, and urea kinetics of beef steers fed isonitrogenous and isoenergetic diets. J Anim Sci 74, 908-916.

INRA (1989) Ruminant Nutrition Recommended Allowances and Feed Tables [R Jarrige, editor]. Paris: INRA/John Libbey Eurotext.

Janes AN, Weekes TEC \& Armstrong DG (1985) Absorption and metabolism of glucose by the mesenteric-drained viscera of sheep fed on dried-grass or ground, maize-based diets. Br J Nutr 54, 449-458.

Kaar WE, Cool LG, Merriman MM \& Brink DL (1991) The complete analysis of wood polysaccharides using HPLC. J Wood Chem Technol 11, 447-463.

Katz ML \& Bergman EN (1969) Simultaneous measurements of hepatic and portal blood flow in the sheep and dog. Am J Physiol 216, 946-952.

Knowlton KF, Glenn BP \& Erdman RA (1998) Performance, ruminal fermentation, and site of starch digestion in early lactation cows fed corn grain harvested and processed differently. J Dairy Sci 81, 1972-1984.

Krehbiel CR, Britton RA, Harmon DL, Peters JP, Stock RA \& Grotjan HE (1996) Effects of varying levels of duodenal or midjejunal glucose and 2-deoxyglucose infusion on small intestinal disappearance and net portal glucose absorption in steers. J Anim Sci 74, 693-700.

Krehbiel CR, Harmon DL \& Schnieder JE (1992) Effect of increasing ruminal butyrate on portal and hepatic nutrient flux in steers. J Anim Sci 70, 904-914.

Kreikemeier KK \& Harmon DL (1995) Abomasal glucose, maize starch and maize dextrin infusions in cattle: small intestinal disappearance, net portal glucose flux and ileal oligosaccharide flow. $\mathrm{Br} J$ Nutr 73, $763-772$.

Kreikemeier KK, Harmon DL, Brandt RT Jr, Avery TB \& Johnson DE (1991) Small intestinal starch digestion in steers: effect of various levels of abomasal glucose, corn starch and corn dextrin infusion on small intestinal disappearance and net glucose absorption. J Anim Sci 69, 328-338.

Kristensen ES, Moller PD \& Hvelplund T (1982) Estimation of the effective protein degradability in the rumen of cows using the nylon bag technique combined with the outflow rate. Acta Agric Scand 32, $123-127$.

Kristensen NB, Pierzynowski SG \& Danfaer A (2000) Portal-drained visceral metabolism of 3-hydroxybutyrate in sheep. J Anim Sci 78, $2223-2228$.

Kung L Jr, Tung RS \& Carmean BR (1992) Rumen fermentation and nutrient digestion in cattle fed diets varying in forage and energy source. Anim Feed Sci Technol 39, 1-12.

Lassalas B, Jouany JP \& Broudiscou L (1993) Dosage des bases puriques et pyrimidiques par chromatographie liquide haute perforlance. Ann Zootech 42, 170-171.

Lee RW, Galyean ML \& Lofgreen GP (1982) Effects of mixing whole shelled and steam flaked corn in finishing diets on feedlot performance and site and extent of digestion in beef steers. J Anim Sci 55, 475-483.

Lemosquet S, Rigout S, Bach A, Rulquin H \& Blum JW (2004a) Glucose metabolism in lactating cows in response to iso energetic infusions of propionic acid or duodenal glucose. J Dairy Sci 87, 1767-1777.

Lemosquet S, Thibault JN, Thomas A, Debras E \& Hurtaud C (2004b) Validation of the measurement of glucose appearance rate with $\left[6,6-{ }^{2} \mathrm{H}_{2}\right]$ glucose in lactating dairy cows. Reprod Nutr Dev $\mathbf{4 4}$, $17-27$.

Lykos T \& Varga GA (1995) Effects of processing method on degradation characteristics of protein and carbohydrate sources in situ. J Dairy Sci 78, 1789-1801.

McAllister TA, Philippe RC, Rode LM \& Cheng KJ (1993) Effect of the protein matrix on the digestion of cereal grains by ruminal microorganisms. J Anim Sci 71, 205-212.

Mertens DR (1993) Kinetics of cell wall digestion and passage in ruminants. In Forage Cell Wall Structure and Digestibility, pp. 535-570 [HG Jung, DR Buxton, RD Hatfield and J Ralph, editors]. Madison, WI: ASA, CSSA, SSSA.

Michalet-Doreau B \& Doreau M (1999) A review: maize genotype and ruminant nutrition. Sci Aliments 19, 349-365.

Nocek JE \& Tamminga S (1991) Site of digestion of starch in the gastrointestinal tract of dairy cows and its effect on milk and composition. J Dairy Sci 74, 3598-3629.

Nozière P \& Hoch T (2005) Modelling fluxes of volatile fatty acids from rumen to portal blood. In Nutrient Digestion and Utilisation in Farm Animals: Modeling Approaches [E Kebreab, J Dikstra, A Bannink, WJJ Gerints and J France, editors]. Wallingford: CAB International (In the Press).

Nozière P, Martin C, Rémond D, Kristensen NB, Bernard R \& Doreau M (2000) Effect of composition of ruminally-infused short-chain fatty acids on net fluxes of nutrients across portal-drained viscera in underfed ewes. Br J Nutr 83, 521-531.

Nozière P \& Michalet-Doreau B (1997) Effects of amount and availability of starch on amylolytic activity of ruminal solid-associated microorganisms. J Sci Food Agric 73, 471-476.

Nozière P, Michalet-Doreau B, Rémond D, Fernandez I, Philippeau C \& Poncet C (2003) Relationship between in sacco degradation and ruminal digestion of starch. Trop Subtrop Agroecosyst 3, 307-311.

Offner A \& Sauvant D (2004) Prediction of in vivo starch digestion in cattle from in situ data. Anim Feed Sci Technol 111, 41-56.

Owens FN, Zinn RA \& Kim YK (1986) Limits to starch digestion in the ruminant small intestine. J Anim Sci 63, 1634-1648.

Philippeau C, Le Deschault de Monredon F \& Michalet-Doreau B (1999a) Relationship between ruminal starch degradation and the physical characteristics of corn grain. J Anim Sci 77, 238-243.

Philippeau C, Martin C \& Michalet-Doreau B (1999b) Influence of grain source on ruminal characteristics and rate, site, and extent of digestion in beef steers. J Anim Sci 77, 1587-1596.

Piccioli Cappelli F, Seal CJ \& Parker DS (1997) Glucose and $\left[{ }^{13} \mathrm{C}\right]$ leucine metabolism by the portal-drained viscera of sheep fed on dried grass with acute intravenous and intraduodenal infusions of glucose. $\mathrm{Br} \mathrm{J}$ Nutr 78, 931-946.

Poncet C, Michalet-Doreau B, McAllister T \& Rémond D (1995) Dietary compounds escaping rumen digestion. In Recent Developments in the Nutrition of Herbivores. Proceedings of the IVth International Symposium on Nutrition of Herbivores, pp. 167-204 [M Journet, E Grenet, MH Farce, M Thériez and C Demarquilly, editors]. Paris: INRA Editions.

Rémond D, Bernard L, Chauveau B, Nozière P \& Poncet C (2003) Digestion and nutrient net fluxes across the rumen, and the mesentericand portal-drained viscera in sheep fed with fresh forage twice daily: net balance and dynamic aspects. Br J Nutr 89, 649-666.

Rémond D, Cabrera JI, Champion M, Chauveau B, Coudure R \& Poncet C (2004) Effect of corn particle size on site and extent of starch digestion in lactating dairy cows. J Dairy Sci 87, 1389-1399.

Rémond D, Ortigues I \& Jouany JP (1995) Energy substrates for the rumen epithelium. Proc Nutr Soc 54, 95-105.

Reynolds CK \& Huntington GB (1988) Partition of portal-drained visceral net flux in beef steers. 1. Blood flow and net flux of oxygen, glucose and nitrogenous compounds across stomach and post-stomach tissues. Br J Nutr 60, 539-551. 
Reynolds CK, Tyrell HF \& Reynolds PJ (1991) Effects of diet forageto-concentrate ratio and intake on energy metabolism in growing beef heifers: net nutrient metabolism by visceral tissues. J Nutr 121, 1004-1015.

Reynolds CK, Tyrell HF \& Armentano LE (1992) Effects on mesenteric vein $n$-butyrate infusion on liver metabolism by beef steers. J Anim Sci 70, 2250-2261.

Seal CJ \& Parker DS (1994) Effect of intraruminal propionic acid infusion on metabolism of mesenteric- and portal-drained viscera in growing steers fed a forage diet: I. Volatile fatty acids, glucose, and lactate. $J$ Anim Sci 72, 1325-1334.

Seal CJ \& Parker DS (1996) Effect of intraruminal propionic acid infusion on metabolism of mesenteric- and portal-drained viscera in growing steers fed a forage diet: II. Ammonia, urea, amino acids, and peptides. J Anim Sci 74, 245-256.

Seal CJ, Parker DS \& Avery PJ (1992) The effect of forage and forageconcentrate diets on rumen fermentation and metabolism of nutrients by the mesenteric- and portal-drained viscera in growing steers. $\mathrm{Br} \mathrm{J}$ Nutr 67, 355-370.

Sharp WM, Johnson RR, Owens FN \& Ruminal VF (1982) A production with steers fed whole or ground corn grain. J Anim Sci 55, 1505-1514.

Siciliano-Jones J \& Murphy MR (1989) Production of volatile fatty acids in the rumen and cecum-colon of steers as affected by forage-concentrate and forage physical form. J Dairy Sci 72, 485-492.

Siddons RC, Paradine J, Beever DE \& Cornell PR (1985) Ytterbium acetate as a particulate-phase digesta-flow marker. Br J Nutr 54, 509-519.
Statistical Analysis Systems (1996) SAS/STAT ${ }^{\circledR}$ User's Guide. Cary, NC: SAS Institute Inc

Stock RA, Brink DR, Britton RA, Goedeken FK, Sindt MH, Kreikemeier KK, Bauer ML \& Smith KK (1987) Feeding combinations of high moisture corn and dry-rolled sorghum in finishing steers. J Anim Sci 65, 290-302.

Swanson CK, Richards CJ \& Harmon DL (2002) Influence of abomasal infusion of glucose or partially hydrolysed starch on pancreatic exocrine secretion in beef steers. J Anim Sci 80, 1112-1116.

Taniguchi K, Huntington GB \& Glenn BP (1995) Net nutrient flux by visceral tissues of beef steers given abomasal and ruminal infusion of casein and starch. J Anim Sci 73, 236-249.

Tucker VA (1967) Method for oxygen content and dissociation curves on microliter blood samples. J Appl Physiol 23, 410-414.

Van Soest PJ \& Robertson JB (1980) Systems of analysis for evaluating fibrous feeds. In Standardization of Analytical Methodology for Feeds, pp. 49-60 [WJ Pigden, CC Balch and M Graham, editors] Ottawa: International Development and Research Center.

Waldo DR, Smith LW, Cox EL \& Lucas HL (1971) Logarithmic normal distribution for description of sieved forage materials. J Dairy Sci 54, $1465-1469$.

Walker JA \& Harmon DL (1995) Influence of rumial or abomasal starch hydrolysate infusion on pancreatic exocrine secretion and blood glucose and insulin concentration in steers. J Anim Sci 73, 3766-3774.

Yang WZ \& Poncet C (1993) Measurements of microbial nitrogen flow in the duodenum in sheep. Ann Zootech 42, 167. 